\title{
A Stakeholder Analysis of the KLIA2 Airport Terminal Project
}

\author{
Nor Azlina Mohd Isa, Norlida Abdul Hamid, Tan Peck Leong
}

\author{
Arshad Ayub Graduate Business School, \\ Universiti Teknologi MARA, Malaysia
}

azlina.isa@gmail.com

\begin{abstract}
Managing an airport terminal project is complex due to the involvement of a large number of stakeholders. Airport stakeholders include many organisations and individuals, making it a collaborative service environment. Stakeholder theory denotes that organisation should strive to create value for all its stakeholders without the need to trade off. This study attempted to provide an overview of the literature relating to the stakeholder theory as well as examining the related respondents towards measuring the collective perspectives of the klia2 airport terminal project.

Keywords: stakeholder theory; airport stakeholders; airport terminal; project management

eISSN 2398-4295 @ 2018. The Authors. Published for AMER ABRA cE-Bs by e-International Publishing House, Ltd., UK. This is an open-access article under the CC BY-NC-ND license (http://creativecommons.org/licenses/bync-nd/4.0/). Peer-review under responsibility of AMER (Association of Malaysian Environment-Behaviour Researchers), ABRA (Association of Behavioural Researchers on Asians) and $c E-B s$ (Centre for EnvironmentBehaviour Studies), Faculty of Architecture, Planning \& Surveying, Universiti Teknologi MARA, Malaysia.

DOI: http://dx.doi.org/10.21834/ajbes.v3i13.138
\end{abstract}




\subsection{Introduction}

The recently developed airport terminal has evolved from merely functioning as a terminal for aviation related travel activities to a multimodal transportation hub and has become a terminal housed with commercial and hospitality services, in addition to basic air travel related services. An airport terminal project, in particular for a major airport of a country, has always been treated as the nation's project and most of the time is an iconic architectural statement, since it is the main gateway to the country. Managing large-scale construction projects has been known to come with many challenges (Toor \& Ogunlana, 2009). Complexity is added to the equation for an airport development project as it involves multiple stakeholders with different goals and objectives (Schaar \& Sherry, 2010). Furthermore, airport stakeholders come in the forms of various organisations as well as many individuals. Stakeholders' involvements in any airport development project are inevitable (Harrison et al., 2012, Schaar \& Sherry, 2010). An airport terminal accommodates many stakeholders who operate, reside or use the terminal as passengers as well as other users. The contradicting needs of various stakeholders impose an enormous challenge for the project owner especially in the decisionmaking process, from the project inception to implementation stages in determining the requirements that create value for all stakeholders. Studies suggest that identification and engagement of interested parties in the early phase of construction and proper management of stakeholders will help to increase the acceptance of the project by public (Sözüern\& Spang, 2014) and enhance the project outcome (Fageha \& Aibinu, 2013).

From the airport operator and project owner perspectives, apart from the right sizing and design capacity, it is fairly vital for an airport terminal to take into consideration all stakeholders' requirements during the planning, design and execution stages, for the terminal to fit its intended operational function. However, there is a limit to adhering to various stakeholders' requests as some of the requirements may conflict with the design intent and the concept of operations of the terminal building and the business objectives of the owner of the project. Furthermore, the process to capture end user requirements are also complex and may not possibly be direct from the source for all stakeholders. Schaar \& Sherry (2010) stressed that the different needs of the airport stakeholders may not necessarily be under the airport management's control.

The klia2 terminal was commissioned in May 2014, replacing the Low Cost Carrier Terminal (LCCT) of the KL International Airport which has been operating since March 2006. The project received extensive media coverage from its inception to its operational days due to criticisms from its main operating airline towards the project and the project owner which is also the airport operator. The Public Accounts Committee (PAC) and the Auditor General (AG) office were directed to audit the project despite the fact that it was privately funded by the airport operator, namely Malaysia Airports Holdings Berhad (MAHB) (AG to audit klia2, 2015).

\section{0 Literature Review}

Freeman (1984) developed the stakeholder theory where it assessed the role of actors in the firm's internal and external environment in relation to managing the business in the turbulent 
times of the 21st Century. It is a theory of organisational management and ethics within the field of strategic management. The goal of the stakeholder approach is for firms to look for a fit between both the company and its stakeholders' interests to maximise firms' performance. Management of a firm needs to ensure that they can find a healthy balance in its relationship with its various stakeholders. The stakeholder theory is viewed as either a complementary or an opposite to the Theories of the Firm where a company's purpose is defined as 'to maximise shareholders wealth'. The stakeholder theory suggests that in maximising shareholders' wealth, the company should take into consideration its other stakeholders' interest as well. Dohnalová \& Zimola (2014) insisted that stakeholder relationship management is vital in increasing a company's competitive advantage.

The theory is further developed, discussed and defined from various perspectives and angle (Freeman et al., 2010). Stieb (2009) insisted that criticism of Freeman's Stakeholder theory be inevitable, as it is eminent and is a very famous theory of business management that came out from a philosophical school of thinking. He was also concerned whether the stakeholder approach will improve any of the problems it was trying to address. Stakeholders may eventually make claims against firms which in turn affect the company's sustainability. In his opinion, there are serious repercussions to any company if the decision-making power is suggested to shift from the shareholders to the stakeholders of a firm.

Stakeholder theory was established to resolve the problems related to business (trade) and value creation, and yet research on value creation itself from the stakeholder perspective is limited (Freeman et al., 2010). Similar to the theory itself, there is also the narrow and broad definition of stakeholder value creation. The narrow view emphasises on small groups of stakeholders such as end users or shareholders while another view covers a larger set of stakeholder groups. According to Argandona (2011), an economic optimum is achieved when maximisation of value happened to all stakeholders, in line with the emphasis on the broad view of stakeholder value creation. Fitrijanti (2015) offered to simplify and operationalise the value concept by exploring means to quantify stakeholder value. However, complexity will remain as maximisation of each stakeholder does not guarantee efficient and fair distribution of value to all. The concept of value goes beyond economic value, making it more realistic to maximise value for all stakeholders. The challenge for value creation in the context of stakeholder theory is to generate a universal value which everybody needs instead of competing for scarce resources. Schaar \& Sherry (2010) conducted an analysis of the stakeholders for airports which consists of fifteen (15) stakeholder groups. The list of airport stakeholders groups is as follows:

Passengers

Organisations

Air Carriers (airlines)

General Aviation

Airport Organisation

Investors and bondholders

Concessionaires

Service Providers

Employees 
Federal Government

Local Government

Communities affected by airport operations

Non-Government Organizations (NGO), such as environmental bodies

Parking operators and ground transportation providers

Airport Suppliers

Each stakeholder group has different goals and objectives for the airport. All the stakeholder groups are relevant to the klia2 project except for General Aviation (GA) since there are no GA movements at the klia2 terminal. An identification of the klia2 Airport Terminal Project stakeholders was mapped based on the stakeholders groups from the research works of Stakeholder theory (Freeman, 1984), Airport stakeholder analysis (Schaar \& Sherry, 2010) and Construction stakeholders (Yang \& Shen, 2014).

Internal and external stakeholder groups of the klia2 project were identified, following the stakeholder groups as listed in the above research. The definition of internal stakeholders refers to parties belonging directly to the organisation while externals are outside the organisation which in this case is MAHB. According to the Project Management Institute (2013), project stakeholders are defined as 'all members of the project team as well as all interested entities that are internal or external to the organisation'. The purpose of identifying project stakeholders apart from the project team is to ensure that the project requirements address the overall stakeholders' needs and expectations, towards ensuring a successful project outcome. The Project Management Institute (2013) also mentioned operational stakeholders and is defined as 'stakeholders who perform and conduct business operations related to the project'. In the context of this research, the operational stakeholders are categorised as the operational and end users of the klia2 terminal, which consists of the following stakeholder groups:

Airport employees

Passengers

Airlines

Airport service providers

Concessionaires

Hotel operators

Public transport operators

Special interest groups

Customs, Immigration, Quarantine, Police (Government Agencies operating at the airport terminal)

By elimination process, the project stakeholders are listed from the remaining stakeholder groups and can be listed as follows:

Airport organisation

Airport owners/shareholders

Appointed contractors

Appointed consultants

Local Government

Federal Government 
Utility companies

\subsection{Methodology}

According to Turner \& Zolin (2012), the project managers' perception of customer, end users and operators' satisfaction are mainly related to the project specifications. The satisfaction aspect is true for various implications of a project such as a project output, outcome and impact. Therefore, it was suggested that satisfaction towards project specification may be used by project stakeholders to predict the customers, end users and operators' satisfaction. This opinion is in line with research by Bezerra \& Gomes (2015) who used the airport facilities and services as the service quality dimension that predicts the overall satisfaction of airport passengers. The service quality dimensions used by Bezerra \& Gomes (2015) were consistent with the industry best practices such as the Airport Service Quality (ASQ) survey for measuring airport passengers' satisfaction.

Customer satisfaction is vital for all types of businesses. Elements of customers' satisfaction get even more complex for service industries as it involves many aspects of the services as well as managing the customer's expectation. Furthermore, it relates to the intangible items unlike a physical product (Bezerra \& Gomes, 2015). Customers for an airport include both organisations and individuals. Ultimately, the main customers at the airport are the passengers. Various studies have looked into the factors which enhance or distract passenger's satisfaction (Bogicevic et al., 2013). They also discussed that many studies have started to focus on delighting the passengers and not merely satisfying them.

It is the right time to measure the outcome of the project from the stakeholders' perspectives especially the end users since it has been almost three years after the commissioning of the klia2 terminal. Finch (2003) conducted a post project evaluation using the Project Implementation Profile (PIP) to measure the project outcome of an information system project from both project team and the end user's perspectives. The (PIP) has been used to measure project performance from various project stakeholders' perspective. Therefore, it is proposed as a suitable instrument for this research to measure satisfaction for organisations which are the stakeholders of the project. However, there is very limited information whether the instrument has been used against end users of the project other than the clients and the project team members, as suggested by Rosacker et al. (2010). The instrument has mainly been used against project managers and technical personnel and professionals involved in project management (Rosacker et al., 2010; Finch, 2003). As for passengers who are the ultimate end users of the terminal, their satisfaction towards the service quality dimensions of the airport terminal facilities could be measured to reflect their overall satisfaction of the terminal (Bezerra \& Gomes, 2015). The main statistical tool proposed to analyse the factors affecting stakeholders' satisfaction is multiple linear regression analysis.

\subsection{Conclusion}

An organisation often mirrors their stakeholders' needs and requirements via their internal 
departments and divisions. Various departments in the organization exist to handle issues related to customers' satisfaction, investors' relations, airlines relations, authorities and regulatory requirements. For an airport terminal project, the stakeholders are a large group of organisations and individuals. During the project implementation, the project stakeholders which consist of both internal and external stakeholders would be required to collaborate to mirror the need for the operational stakeholders which are the operators and end users of the terminal. The main challenge would be whether the project stakeholders accurately emulate the operational stakeholders' needs and whether the value created by the project is relevant to all stakeholders. Based on the literature reviews, projects' outcome have been assessed mainly through the project managers' perspective and only recently through the project owners' and selected stakeholders' perspectives. The gap identified from literature stated that the satisfaction of project outcome was rarely examined from an overall stakeholders' perspective. Therefore, there is a need to measure the perception of the project outcome for all stakeholders for the klia2 project and obtain the collective perspectives of the various stakeholders. Although it may neither be possible to achieve consensus nor would it be expected to obtain high satisfaction results from the majority of the stakeholders, it is still worthwhile to analyse the results for the benefit of future projects.

\section{Acknowledgement}

Special thanks to the Ministry of Higher Education of Malaysia, Malaysia Airports Holdings Berhad and Universiti Teknologi MARA and all reviewers for their reviews and comments on this paper.

\section{References}

AG to audit klia2. (2015, May 23). New Straits Times (Malaysia)

Argandoña, A. (2011). Stakeholder theory and value creation, Working Paper, WP-922.

Bezerra, G.C.L. \& Gomes, C.F. (2015). The effects of service quality dimensions and passengers characteristics on passenger's overall satisfaction with an airport. Journal of Air Transport Management, 44 - 45, 77 - 81.

Bogicevic, V., Yang, W., Bilgihan, A. \& Bujisic, M. (2013), Airport service quality drivers of passenger satisfaction. Tourism Review, 68(4), 3 - 18.

Dohnalová, Z., \& Zimola, B. (2014). Corporate Stakeholder Management. Procedia - Social and Behavioral Sciences, 110, 879-886.

Fageha, M. K., \& Aibinu, A. a. (2013). Managing Project Scope Definition to Improve Stakeholders' Participation and Enhance Project Outcome. Procedia - Social and Behavioral Sciences, 74, 154-164.

Finch, P. (2003). Applying Slevin-Pinto Project Implementation Profile to an Information Systems Project. Project Management Journal, 34(3), 32-39.

Fitrijanti, T. (2015). Index of the Company's Stakeholders Welfare. Procedia - Social and Behavioral Sciences, 
211(September), 1023-1027.

Freeman, R.E, Harrison, J.S., Wicks, A.C, Parmar, B. \& Simone de Colle. (2010). Stakeholder Theory: The State of the Art. New York. Cambridge University Press.

Freeman, R.E (1984). Strategic Management: A Stakeholder Approach. Boston. Pitman Publishing Inc.

Harrison, A., Popovic, V., Kraal, B. J., \& Kleinschmidt, T. (2012). Challenges in passenger terminal design : A conceptual model of passenger experience. Proceedings of the Design Research Society, 344-356.

Hussein, H., \& Yaacob, N. M. (2013). Malaysian perspective on the development of accessible design, Asian Journal of Environment-Behaviour Studies, 4(12), 101-116.

Project Management Institute. (2013). A guide to project management body of knowledge (PMBOK guide). Newton Square, Pa: Project Management Institute

Rosacker, K. M., Zuckweiler, K. M., \& Buelow, J. R. (2010). An empirical evaluation of hospital project implementation success. Academy of Health Care Management Journal VO - 6, 6(1), 37.

Schaar, D. \& Sherry. L. (2010). Analysis of Airport Stakeholders, Integrated Communications Navigation and Surveillance Conference (ICNS), J4 1-17.

Sözüer, M., \& Spang, K. (2014). The Importance of Project Management in the Planning Process of Transport Infrastructure Projects in Germany. Procedia - Social and Behavioral Sciences, 119(0), 601-610.

Stieb, J. A. (2009). Assessing Freeman's stakeholder theory. Journal of Business Ethics. 87, 401-414.

Toor, S.-R. \& Ogunlana, S. O. (2009). Construction professionals' perception of critical success factors for largescale construction projects. Construction Innovation: Information, Process, Management, 9(2), 149-167.

Turner, R. \& Zolin, R. (2012). Forecasting success on large projects: developing reliable scales to predict multiple perspectives by multiple stakeholders over multiple time frames, Project Management Journal, 43(5), 87 - 99.

Yang R.J. \& Shen, G.Q.P. (2014). Framework for stakeholder management in construction projects. Journal of Management in Engineering, 31(4), 1-14. 